\title{
EXPERIMENTAL PLEURODESIS INDUCED BY ANTIBIOTICS (MACROLIDES OR QUINOLONES)
}

Lisete R. Teixeira, Francisco S. Vargas, Milena M. P. Acencio, Renan U. M. Bumlai, Leila Antonangelo, Evaldo Marchi

\begin{abstract}
Teixeira LR, Vargas FS, Acencio MMP, Bumlai RUM, Antonangelo L, Marchi E. Experimental pleurodesis induced by
\end{abstract} antibiotics (macrolides or quinolones). Clinics. 2006;61(6):559-64.

PURPOSE: Chemical pleurodesis is a therapeutic tool for the treatment of recurrent pleural effusions, mainly those of neoplastic etiology. In the past, tetracycline was the sclerosant agent of choice in clinical practice, but presently, there is no consensus about an ideal agent. The aim of this study was to evaluate the effectiveness of macrolides (azithromycin and clarithromycin) or quinolones (levofloxacin and gatifloxacin) in inducing experimental pleurodesis in rabbits.

METHOD: Forty New Zealand rabbits randomized into groups of 10 received (at a total volume of $2 \mathrm{~mL}$ for each animal) 1 of the 4 drugs by intrapleural injection. After 28 days, the animals were euthanized and the pleural cavity was evaluated macroscopically and microscopically.

RESULTS: The intensity of the macroscopic adhesions was mild in all groups. On microscopic analysis, minimal pleural fibrosis and inflammation were observed in all animals.

CONCLUSION: The macrolides (azithromycin or clarithromycin) and the quinolones (levofloxacin or gatifloxacin) when injected into the normal pleural space of rabbits are not effective in promoting pleurodesis. Additional research is required to identify sclerosing agents capable of inducing pleurodesis.

KEYWORDS: Pleural effusion. Pleurodesis. Macrolides. Quinolones.

\section{INTRODUCTION}

Chemical pleurodesis is a method used to treat recurring pleural effusions, especially those with malignant etiology in which symphysis between the pleural layers is needed. ${ }^{1}$ Intrapleural instillation of a sclerosing agent that acts on the mesothelial layer leads to an inflammation that progresses to a fibrotic process and coalesces the parietal and visceral layers, obliterating the pleural space and producing pleurodesis. ${ }^{1}$

The choice of a sclerosing agent is still controversial. An ideal sclerosant would be low cost, easily available,

Pleura Laboratory, Pulmonary Division, Heart Institute (InCor), São Paulo University Medical School - São Paulo/SP, Brazil.

Email: pnelisete@incor.usp.br

Received for publication on May 26, 2006.

Accepted for publication on October 23, 2006. easily manipulated and sterilized; it would produce low morbidity (eg, pain should be easily controlled), and no mortality. ${ }^{2}$ To date, no sclerosant agent with all these characteristics has been identified.

The most frequently used sclerosants are antibiotics (doxycycline), antineoplastic agents (bleomycin), immunostimulants (C. parvum), and irritants (talc). ${ }^{2}$ The effectiveness of antibiotics varies between $60 \%$ and $80 \%$, of antineoplastic agents between $60 \%$ and $70 \%$, and for irritants, it is generally greater than $90 \% .^{2,3}$ Although talc might be considered an ideal agent, several cases of acute respiratory distress syndrome have been reported in association with talc pleurodesis. ${ }^{2,4,5}$

Among antibiotic sclerosants, tetracycline was the first choice for several decades. It was abandoned as a result of a commercial decision that discontinued its production. ${ }^{2}$ Derivatives of tetracycline, doxycycline and minocycline, were its natural replacements for inducing pleurodesis., ${ }^{2,6-8}$ 
Macrolides have been used to induce pleurodesis. Erythromycin was used in an experimental model as a sclerosing agent, with inflammation and fibroblast proliferation being evident after 8 days. ${ }^{9}$ In a clinical trial evaluating 15 patients with malignant pleural effusion, erythromycin was effective inducing pleurodesis in $84 \%$ of cases. ${ }^{10}$

Quinolones are widely used broad-spectrum antibiotics. Nevertheless, as far as we know, there have been no clinical or experimental studies evaluating pleural sclerosis production with this drug.

This study aimed to evaluate, using an experimental model in rabbits, the effectiveness of intrapleural instillation of macrolides (azithromycin or clarithromycin) or quinolones (levofloxacin or gatifloxacin) in inducing pleurodesis.

\section{METHODS}

This study was carried out at the Pleura Laboratory and the Research Division of the Heart Institute, Hospital das Clínicas, São Paulo University Medical School [HCFMUSP], having been previously approved by the Institutional Ethics Committee.

Forty New Zealand rabbits weighing 2.0 to $3.0 \mathrm{~kg}$, randomized into 4 groups (with 10 animals each), received (in a total volume of $2 \mathrm{~mL}$ ) by intrapleural injection, 15 $\mathrm{mg} / \mathrm{kg}$ of azithromycin or clarithromycin or $10 \mathrm{mg} / \mathrm{kg}$ of levofloxacin or gatifloxacin.

The surgical procedure followed a previously described methodology. ${ }^{8,11,12}$ After anesthesia by intramuscular injection ( $35 \mathrm{mg} / \mathrm{kg}$ of ketamine $\mathrm{HCl}$ and $5 \mathrm{mg} / \mathrm{kg}$ of xylazine hydrochloride), the animals were prepared for aseptic surgery. After an incision $(0.5 \mathrm{~cm})$ in the right hemithorax, the parietal pleura was exposed and the sclerosing agent was injected into the pleural space through a drain $(6 \mathrm{~F})$; the surgical wound was closed by sutures. The drain, aspirated daily, was removed after 48 hours if the daily fluid outflow was less than $1 \mathrm{~mL} /$ day. The left hemithorax served as a control and did not receive intrapleural instillation of any substance or drain.

According to the protocol, animals exhibiting apparent distress were immediately euthanized.
After 28 days, the surviving animals were euthanized by an IV injection of $40 \mathrm{mg} / \mathrm{kg}$ of pentobarbital into the marginal ear vein. The thorax was removed en bloc, and the lungs were expanded with $60 \mathrm{~mL}$ of $10 \%$ formalin and immerged in this solution for at least $48 \mathrm{~h}$. After this period, each pleural cavity was exposed using the method previously described by our group. ${ }^{13-16}$ Then, with the thorax opened, we evaluated the presence of macroscopic pleural adhesions and collected fragments from the pleura and pulmonary parenchyma for later microscopic analysis.

Table 1 summarizes scoring scheme for adhesion, atelectasis, and fluid collection. Such scores were established in order to macroscopically quantify the degree of pleural adhesion (0-4), atelectasis (0-2), and fluid collection (0-4). Pleurodesis was considered effective when the degree of pleural adhesions was equal to or greater than a score of $3^{11-16}$ and no presence of atelectasis or fluid collection. Table 1 also shows the scores used to quantify collected fragments of pleura and parenchyma; these were processed and stained with hematoxylin and eosin. Similarly to the macroscopic assessment, we based our microscopic analysis on previously validated scores, ${ }^{13-16}$ quantifying the degree of inflammation and fibrosis (0 to 4$)$.

The descriptive statistics developed were mean and standard deviation. Group means were tested for significant differences using the $t$ test to compare the 2 groups of antibiotics (macrolides vs quinolones) and ANOVA followed by multiple comparison tests (Tukey or Dunn) to compare the groups among themselves. Statistical significance was considered when the difference was less than or equal to 0.05 .

\section{RESULTS}

Only 1 death was observed, and it occurred on the second postoperative day. Necropsy revealed no significant alterations in the pleural space that could have contributed to the lethal outcome (this case was excluded from the statistical analysis). The side effects of the drugs injected were acute episodes of diarrhea 3 hours after the intrapleural injection in more than $75 \%$ of the animals that received

Table 1 - Scoring scheme for the macroscopic and microscopic evaluations of the pleura

\begin{tabular}{|c|c|c|c|c|c|}
\hline degree of & 0 & 1 & 2 & 3 & 4 \\
\hline adhesions & normal pleura & 1 - 3 small & $\begin{array}{l}>3 \text { adhesions } \\
(\text { easy separation*) }\end{array}$ & $\begin{array}{l}\text { generalized } \\
\text { (difficult separation*) }\end{array}$ & $\begin{array}{l}\text { pleural space } \\
\text { obliteration }\end{array}$ \\
\hline atelectasis & none & partial & total & - & - \\
\hline $\begin{array}{l}\text { fluid colletion } \dagger \\
\text { inflammation and } \\
\text { fibrosis }\end{array}$ & $\begin{array}{l}\text { absent } \\
\text { normal pleura and } \\
\text { parenchima }\end{array}$ & $\begin{array}{l}<25 \% \\
\text { minimal }\end{array}$ & $\begin{array}{l}\geq 25-<50 \% \\
\text { discreet }\end{array}$ & $\begin{array}{l}\geq 50-<75 \% \\
\text { moderate }\end{array}$ & $\begin{array}{l}\geq 75 \% \text { of cavity } \\
\text { severe }\end{array}$ \\
\hline
\end{tabular}

*: lung thorax separation; $\uparrow: \%$ of cavity 
azithromycin or clarithromycin. After 24 hours, the animals returned to normalcy, and no drug intervention was necessary. These episodes of diarrhea were not observed with the intrapleural use of quinolones.

No animal presented pleural fluid during the 48 hours after injection of the sclerosing agent (the period in which the drain remained in the animals), and this made sampling for further biochemical or cytological fluid analysis impossible.

\section{Macroscopic Analysis}

The intensity of the adhesions (Table 2) was discreet in the groups that received macrolides $(1.25 \pm 0.75)$ and in those receiving quinolones $(0.64 \pm 0.63)$, and no significant difference $(P=0.057)$ was observed between them. The scores attributed to the adhesions in the animals that received azithromycin $(1.25 \pm 0.50)$, clarithromycin $(1.25$ $\pm 1.04)$, levofloxacin $(1.00 \pm 0.53)$, or gatifloxacin $(0.16$ $\pm 0.41)$ were significantly different $(P=0.033)$, although significant differences were not found from the multiple comparisons test.

In all animals, the left hemithorax, used as a control because it had not been injected with the agent, received a score of 0 .

Table 2 - Scores of pleural adhesions observed macroscopically in the injected hemithorax

\begin{tabular}{lccc}
\hline ANTIBIOTICS & PLEURAL ADHESIONS & $p^{*}$ & $p^{\S}$ \\
\hline Macrolides & $1.25 \pm 0.75$ & 0.057 & \\
Quinolones & $0.64 \pm 0.63$ & & \\
Azithromycin & $1.25 \pm 0.50$ & & 0.033 \\
Clarithromycin & $1.25 \pm 1.04$ & & \\
Levofloxacin & $1.00 \pm 0.53$ & & \\
Gatifloxacin & $0.17 \pm 0.41$ & &
\end{tabular}

*macrolides x quinolones ( $t$ test); ${ }^{\circledR}$ azithromycin $\mathrm{x}$ clarithromycin $\mathrm{x}$ levofloxacin $\mathrm{x}$ gatifloxacin (ANOVA)

\section{Microscopic Analysis}

The microscopic changes observed in the visceral pleura resulting from the intrapleural injection of the agents investigated were minimal on the right and absent (score = 0 ) on the left. These results (Table 3 ) were both observed in the group dosed with macrolides (fibrosis: $0.94 \pm 0.73$, inflammation: $0.37 \pm 0.52$ ) and in the group dosed with quinolones (fibrosis: $0.43 \pm 0.51$, inflammation: $0.36 \pm$ 0.50 ), with no significant differences (fibrosis: $P=0.108$, inflammation: $P=0.973$ ).

The pleural fibrosis scores resulting from injections of azithromycin $(0.37 \pm 0.48)$, clarithromycin $(1.50 \pm 0.41)$, levofloxacin $(0.62 \pm 0.52)$, or gatifloxacin $(0.17 \pm 0.41)$ were significantly different one from the other $(P=0.002)$. Tukey's test showed that this difference was a result of the comparison between clarithromycin and the other drugs.

Regarding pleural inflammation, there was no significant difference among the groups $(P=0.553)$. The scores attributed were $0.25 \pm 0.50 ; 0.50 \pm 0.58 ; 0.50 \pm 0.54$, and $0.17 \pm 0.41$ for azithromycin, clarithromycin, levofloxacin, and gatifloxacin, respectively.

The pulmonary parenchyma was not affected by the intrapleural injection of these agents (score $=0$ ).

\section{DISCUSSION}

This study demonstrates that the intrapleural injection of azithromycin, clarithromycin, levofloxacin, or gatifloxacin is not effective in inducing pleurodesis in an experimental rabbit model. The degree of pleural adhesion after the intrapleural injection of these drugs was notably inferior to that observed in a prior study after the pleural instillation of talc $(2.2 \pm 0.7)$ or silver nitrate $(3.2 \pm 1.1){ }^{12}$

The choice of an ideal pleural sclerosing agent is still object of research and is based on efficacy, morbidity-mortality, ease in manipulation, availability, and cost. It is note worthy that although the century have elapsed since pleurodesis was first performed $(1901)^{2,7}$, the ideal agent only have far been identified. The nonexistence of a substance that satisfies all the basic prerequisites and clinical needs explains the ongoing research, including the revival of studies on agents that had been used in the past. ${ }^{17,18}$

The interest in antibiotics as pleural sclerosing agents dates back to the early phases of studies on pleurodesis. The first antibiotic used in clinical practice was tetracycline, which was used until the 1980s when production of the injectable form was discontinued. Tetracycline was immediately replaced, although without the same impact, by its natural derivatives, doxycycline, and minocycline. ${ }^{2,3}$ Tetracycline, employed as a pleural sclerosing agent in humans for more than 20 years, was effective in inducing pleurodesis in approximately $70 \%$ of cases, surpassing the currently achieved results obtained with doxycycline and minocycline that experimentally produce pleurodesis in about $80 \%$ of injected animals, but can result in hemothorax and death. ${ }^{8}$

In addition to tetracycline and its derivatives, macrolides, represented by erythromycin, were evaluated for sclerosing effects both in experimental models and in humans. In animals, after a period of 8 days, the intrapleural instillation of erythromycin produces marked inflammation, allowing recognition of its irritant action on pleural layers and suggesting a potential sclerosing effect. ${ }^{9}$ This effect was later confirmed in humans (26 patients) in whom 
effectiveness was observed in $85 \%$ of patients with neoplastic pleural effusion, with a complete response in 15 (58\%). In these $85 \%$ (22) of patients, the formation of numerous pleural adhesions and control of the pleural effusion was noted. ${ }^{10}$

It is important to note that antibiotics, provided that they are inexpensive, effective, and cause few side effects, could be considered ideal agents due to their wide availability. The established sclerosing effectiveness of tetracycline and erythromycin (macrolides), justifies further investigation with other antibiotics.

The mechanisms responsible for producing pleurodesis are not completely clear. Apparently, the instillation of a sclerosing agent causes damage to the mesothelial layer with the subsequent formation of an inflammatory process, characterized by the production of exudative fluid. ${ }^{1,2}$

In spite of prior reports ${ }^{9,10}$ describing the effectiveness of erythromycin, other macrolides such as azithromycin and clarithromycin were not capable of producing a pleural inflammatory process intense enough to induce the formation of pleurodesis. No exudation, evidenced by the presence of pleural effusion, was seen during the first 48 hours of observation. This absence of pleural fluid correlates with the data noted both in the macroscopic and microscopic evaluations.

The nonexistence of fluid suggests a mild effect of these drugs on the pleura. The pleural fluid, characteristically an exudate, expresses acute inflammatory alterations that are the beginning of a succession of events leading to the development of pleural adhesions and the resulting pleurodesis formation. Factors capable of interfering in this progress include the intensity of the injury, the capacity of the mesothelial cells and fibroblasts to secrete collagen, the relative equilibrium between the metaloproteinases and their inhibitors, and the balance between the activators and inhibitors of plasminogen, in addition to the relationship between the inflammation and the pro-inflammatory cytokines with fibrinolysis mechanisms. ${ }^{19,20}$
Earlier studies ${ }^{9,10}$ showing the sclerosing action of erythromycin led to the hypothesis that other macrolides (azithromycin or clarithromycin) might also be capable of promoting mesothelial layer damage sufficient to produce pleural effusion and subsequent pleural adhesions. This was not observed in this study, which might be explained by pharmacokinetic characteristics. In theory, these antibiotics would be rapidly absorbed and might not remain in the pleural cavity long enough to cause mesothelial damage and initiate the necessary inflammatory process. The observation of diarrhea 3 hours after intrapleural dosing of the macrolides suggests precocious systemic manifestations resulting from the rapid absorption and distribution of these antibiotics.

With the objective of finding sclerosing agents with an effect similar to that of tetracycline, and considering the current ample use and wide distribution of quinolones, we chose to evaluate the possible effects of inducing pleurodesis with levofloxacin and gatifloxacin, even though there are no past reports (as far as we know) on the use of these antibiotics.

The pleural adhesions observed after instillation of these agents were not encouraging: there was no acute evidence of pleural fluid formation, and the degree of inflammation noted at microscopic assessment after 28 days was irrelevant, because the degree of pleural adhesion resulting from the experimental treatment was not considered adequate. Therefore, the quinolones analyzed (levofloxacin and gatifloxacin) produced minimal damage to the mesothelium. Thus, the succession of events that might culminate in macroscopically visible pleural adhesions , and microscopically recognizable fibrosis was not established.

The statistical difference observed among the 4 groups analyzed in the macroscopic evaluation of adhesions and the microscopic evaluation of pleural fibrosis was not substantial and has no concrete significance since those scores are irrelevant as noted above.

Although the sclerosing effect of erythromycin had previously been demonstrated in clinical and experimental

Table 3 - Scores for pleural fibrosis and inflammation observed microscopically in the injected hemithorax

\begin{tabular}{|c|c|c|c|c|c|c|}
\hline \multirow{2}{*}{ ANTIBIOTICS } & \multicolumn{2}{|c|}{ FIBROSIS } & \multicolumn{4}{|c|}{ INFLAMMATION } \\
\hline & $\mathrm{X} \pm \mathrm{SD}$ & $p^{*}$ & $p P^{\S}$ & $\mathrm{X} \pm \mathrm{SD}$ & $p^{*}$ & $p^{\S}$ \\
\hline $\begin{array}{l}\text { Macrolides } \\
\text { Quinolones }\end{array}$ & $\begin{array}{l}0.94 \pm 0.73 \\
0.43 \pm 0.51\end{array}$ & 0.108 & & $\begin{array}{l}0.37 \pm 0.52 \\
0.36 \pm 0.50\end{array}$ & 0.973 & \\
\hline $\begin{array}{l}\text { Azithromycin } \\
\text { Clarithromycin } \\
\text { Levofloxacin } \\
\text { Gatifloxacin }\end{array}$ & $\begin{array}{l}0.37 \pm 0.48 \\
1.50 \pm 0.41 \\
0.62 \pm 0.52 \\
0.17 \pm 0.41\end{array}$ & & 0.002 & $\begin{array}{l}0.25 \pm 0.50 \\
0.50 \pm 0.58 \\
0.50 \pm 0.54 \\
0.17 \pm 0.41\end{array}$ & & 0.553 \\
\hline
\end{tabular}

*macrolides x quinolones; ${ }^{\S}$ azithromycin x clarithromycin x levofloxacin $\mathrm{x}$ gatifloxacin 
studies, ${ }^{9,10}$ no significant pleural adhesion was noted in the present experiments, after the intrapleural injections of azithromycin or clarithromycin, also belonging to the macrolide class. Similarly, the studied quinolones (levofloxacin and gatifloxacin) showed no pleural sclerosing effect in our experimental model and therefore should not be considered for use in humans.

These negative results are deliberately collected and offered as a finished study because we firmly believe that they add important data to the field, indicating that additional drugs must be tested with the purpose of identifying the ideal pleural sclerosant.

\section{ACKNOWLEDGEMENTS}

We thank Carlos S. R. Silva, laboratory technician, and Gabriela G. Carnevale, pharmacist, for their help during surgical procedures and care for the animals.

\section{RESUMO}

Teixeira LR, Vargas FS, Acencio MMP, Bumlai RUM, Antonangelo L, Marchi E. Pleurodese experimental induzida por antibióticos (macrolídeos e quinolonas). Clinics. 2006;61(6):559-64.

OBJETIVO: A pleurodese química representa uma ferramenta terapêutica utilizada no tratamento dos processos pleurais recidivantes, principalmente nos derrames neoplásicos. A escolha do melhor esclerosante pleural é ainda motivo de controvérsia, não havendo consenso com relação ao agente considerado ideal. O objetivo deste estudo é avaliar a efetividade dos macrolídeos (azitromicina e claritromicina) e das quinolonas (levofloxacina e gatifloxacina) na indução de pleurodese experimental em coelhos.

MÉTODOS: Quarenta animais randomizados em grupos de 10 , receberam, em volume total de $2 \mathrm{~mL}$, estas drogas através de injeção intrapleural.

RESULTADOS: Após 28 dias, os animais foram sacrificados sendo avaliada a cavidade pleural. A intensidade das aderências macroscópicas assim como da fibrose e da inflamação observadas à microscopia foi discreta tanto no grupo que recebeu macrolídeos quanto naquele que recebeu quinolonas.

CONCLUSÃO: Azitromicina, Claritromicina, Levofloxacina e Gatifloxacina quando injetados na cavidade pleural de coelhos, não são eficazes na indução de pleurodese. Novas pesquisas devem ser realizadas com o intuito de identificar agentes esclerosantes capazes de produzir sínfise pleural.

UNITERMOS: Pleurodese. Macrolídeos. Quinolonas. Azitromicina. Claritromicina. Levofloxacina. Gatifloxacina.

\section{REFERENCES}

1. Light RW, Vargas FS. Pleural sclerosis for the treatment of pneumothorax and pleural effusion. Lung. 1997;175:213-23.

2. Pleurodesis, Vargas FS, Teixeira LR in Pleural Effusion, Vargas FS, Teixeira LR, Marchi E. $1^{\text {st }}$ Ed - Ed Roca, S Paulo - SP, Brazil, 2004

3. Walker-Renard PB, Vaughan LM, Sahn SA. Chemical pleurodesis for malignant pleural effusions. Ann Intern Med. 1994;120:56-64.

4. Rehse DH, Aye RW, Florence MG. Respiratory failure following talc pleurodesis. Am J Surg. 1999;177:437-40.

5. Brant A, Eaton T. Serious complications with talc slurry pleurodesis Respirology. 2001;6:181-85.

6. Light RW, Wang NS, Sassoon CS, Gruer SE, Vargas FS. Comparison of the effectiveness of tetracycline and minocycline as pleural sclerosing agents in rabbits. Chest. 1994;106:577-82.

7. Marchi E, Teixeira LR, Vargas FS. Management of malignancyassociated pleural effusion: current and future treatment strategies. Am J Respir Med. 2003;2:261-73.
8. Wu W, Teixeira LR, Light RW. Doxycycline pleurodesis in rabbits. Comparison of results with and without chest tube. Chest. 1998;114:56368

9. Carvalho P, Knight LL, Olson RD, Crowley JJ, Hawk PA, Charan NB. Effects of erythromycin on the rabbit pleura: its potential role as a pleural sclerosant. Am J Respir Crit Care Med. 1995;151:1228-32.

10. Tang X, Cheng D. The value of erythromycin pleurodesis in the treatment of malignant pleural effusions. Hua Xi Yi Ke Da Xue Xue Bao. 1997;28:437-39.

11. Teixeira LR, Wu W, Cheng DS, Light RW. The effect of corticosteroids on pleurodesis induced by doxycycline in rabbits. Chest. 2002;121:21619.

12. Teixeira LR, Vargas FS, Acencio MM, Paz PF, Antonangelo L, Vaz MA, Marchi E. Influence of anti-inflammatory drugs (methylprednisolone and diclofenac sodium) on experimental pleurodesis induced by silver nitrate or talc. Chest. 2005;128:4041-45. 
13. Teixeira LR, Vargas FS, Antonangelo L, Mattos VC, Vaz MAC, Marchi E. Low concentration silver nitrate pleurodesis in rabbits: optimal concentration for rapid and complete sclerosing effect. Lung. 2003;181:353-59.

14. Vargas FS, Carmo AO, Marchi E, Vaz MAC, Ramos KP, Teixeira LR. Effectiveness of silver nitrate compared to talc slurry as pleural sclerosing agent in rabbits. Influence of concomitant intrapleural lidocaine. Rev. Hosp Clin Fac Med S Paulo. 1999;54:199-208.

15. Vargas FS, Antonangelo L, Capelozzi V, Vaz MAC, Genofre EH, Marchi E, Teixeira LR. Lung damage in experimental pleurodesis induced by silver nitrate or talc. 1-year follow-up. Chest. 2002;122:2122-26.

16. Vargas FS, Teixeira LR, Antonangelo L, Vaz MAC, Carmo AO, Marchi E, Light RW. Experimental pleurodesis in rabbits induced by silver nitrate or talc. 1-year follow-up. Chest. 2001;119:516-20.
17. Vargas FS, Carmo AO, Teixeira LR. A new look at old agents for pleurodesis: nitrogen mustard, sodium hydroxide, and silver nitrate. Curr Opin Pulm Med. 2000;6:281-86.

18. Dikensoy O, Light RW. Alternative widely available, inexpensive agents for pleurodesis. Curr Opin Pulm Med. 2005;11:340-44.

19. Lee YC, Lane KB. The many faces of transforming growth factor-beta in pleural diseases. Curr Opin Pulm Med. 2001;7:173-79.

20. Lee YC, Lane KB, Zoia O,Thompson PJ, Light RW, Blackwell TS. Transforming growth factor-beta induces collagen synthesis without inducing IL-8 production in mesothelial cells. Eur Respir J. 2003;22:197-202 